\section{(6) OPEN ACCESS}

\title{
Bacterial vaginosis among women at high risk for HIV in Uganda: high rate of recurrent diagnosis despite treatment
}

\author{
Suzanna C Francis, ${ }^{1}$ Clare Looker, ${ }^{1}$ Judith Vandepitte ${ }^{2}$ Justine Bukenya, ${ }^{2}$ \\ Yunia Mayanja, ${ }^{2}$ Susan Nakubulwa, ${ }^{2}$ Peter Hughes, ${ }^{2}$ Richard J Hayes, ${ }^{1}$ \\ Helen A Weiss, ${ }^{1}$ Heiner Grosskurth ${ }^{1,2}$
}

- Additional material is published online only. To view please visit the journal online (http://dx.doi.org/10.1136/ sextrans-2015-052160).

${ }^{1}$ MRC Tropical Epidemiology Group, London School of Hygiene and Tropical Medicine, London, UK

${ }^{2}$ MRC/UVRI Uganda Research Unit on AIDS, Entebbe, Uganda

\section{Correspondence to}

Dr Suzanna C Francis, London School of Hygiene and Tropical Medicine, Keppel Street, London WC1E 7HT, UK; suzanna.francis@|shtm.ac.uk

SCF and CL contributed equally

Received 21 May 2015 Revised 9 July 2015 Accepted 12 July 2015 Published Online First 7 August 2015

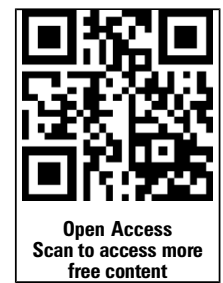

CrossMark

To cite: Francis SC, Looker C, Vandepitte J, et al. Sex Transm Infect 2016;92:142-148.

\section{ABSTRACT}

Objectives Bacterial vaginosis (BV) is associated with increased risk for sexually transmitted infections (STIs) and HIV acquisition. This study describes the epidemiology of BV in a cohort of women at high risk for STI/HIV in Uganda over 2 years of follow-up between 2008-2011.

Methods 1027 sex workers or bar workers were enrolled and asked to attend 3-monthly follow-up visits. Factors associated with prevalent BV were analysed using multivariate random-effects logistic regression. The effect of treatment on subsequent episodes of BV was evaluated with survival analysis.

Results Prevalences of BV and HIV at enrolment were $56 \%(573 / 1027)$ and 37\% (382/1027), respectively. Overall, 905 (88\%) women tested positive for BV at least once in the study, over a median of four visits. Younger age, a higher number of previous sexual partners and current alcohol use were independently associated with prevalent BV. BV was associated with STIS, including HIV. Hormonal contraception and condom use were protective against BV. Among 853 treated BV cases, $72 \%$ tested positive again within 3 months. There was no difference in time to subsequent BV diagnosis between treated and untreated women.

Conclusions BV was highly prevalent and persistent in this cohort despite treatment. More effective treatment strategies are urgently needed.

\section{INTRODUCTION}

Bacterial vaginosis (BV) is a common vaginal condition among women in sub-Saharan Africa, with prevalence ranging from $6 \%$ to $58 \% .^{1} \mathrm{BV}$ is characterised by a reduction in lactic acid-producing lactobacilli and concurrent increase in anaerobic bacteria. BV has been described as a dysbiosis, or a microbial imbalance, and has been associated with preterm delivery, ${ }^{2}$ pelvic inflammatory disease $(\mathrm{PID})^{3}$ and sexually transmitted infections (STIs). ${ }^{1}{ }^{4-6}$ Furthermore, BV increases viral replication and vaginal shedding of $\mathrm{HIV}-1^{7}$ and herpes simplex virus (HSV) $-2,{ }^{8}$ facilitating transmission of these viruses.

BV manifests clinically as a thin, whitish, homogeneous vaginal discharge and the presence of an amine odour. ${ }^{9}$ However, BV is often asymptomatic; in a recent study in South Africa, 90\% of BV cases were asymptomatic. ${ }^{10}$ Current recommendations are that symptomatic BV is treated with oral metronidazole 400-500 mg twice a day for 5-7 days; ${ }^{11} 12$ however, in resource-limited settings, BV is often treated according to WHO recommendations for managing vaginal discharge syndrome (VDS) with $2 \mathrm{~g}$ of metronidazole in a single dose. ${ }^{13}$

Once treated, BV often recurs; treatment trials report cure rates of $80-90 \%$, but recurrence rates of $43 \%$ within 3 months. ${ }^{14}$ However, few studies have reported the recurrence of BV in sub-Saharan Africa where BV prevalence is high. In a study carried out among 35-year-old to 65-year-old women in South Africa, 32\% of women treated for BV had recurrent BV within 12 months. ${ }^{15}$ More research is needed to investigate the occurrence and recurrence of $\mathrm{BV}$ in key populations for HIV infection.

The high prevalence of $\mathrm{BV}$ with its numerous adverse sequelae and high recurrence rates is of increasing international concern, especially in settings with high rates of STIs and HIV. Reducing prevalence of BV has the potential to reduce acquisition of related infections.

Our study aims to describe the epidemiology of $\mathrm{BV}$ in a cohort of women at high risk for STI and HIV infection in Kampala, Uganda. We describe the prevalence of BV over a 24-month period, behavioural and biological factors associated with $\mathrm{BV}$, and the effect of treatment on subsequent diagnosis of BV.

\section{METHODS}

Study design, setting and participants

The study methods have been described previously. ${ }^{16}$ In brief, the Good Health for Women Project is an observational cohort of self-identified sex workers and women working in bars and other entertainment venues in southern Kampala. The study offers free general and reproductive healthcare for participants and their children aged under 5 years. Participants were recruited between 2008 and 2009 and asked to attend follow-up every 3 months. Genital samples were systematically collected for the first 24 months of follow-up.

Participants were included in the study if they were aged at least 18 years or considered a mature minor, involved in high-risk sexual activity and willing to participate in HIV counselling and testing. Participants attended an enrolment 
interview and clinical examination. At each visit, data were collected on socio-demographic factors, alcohol and drug use, intravaginal practices, sexual behaviour, contraception, pregnancy and current symptoms. Blood samples were obtained at every visit; genital sampling and a routine genital examination were carried out at all visits except at months 15 and 21 due to financial constraints. Genital symptoms were recorded at every visit, and participants with symptoms consistent with PID, VDS or genital ulcer disease (GUD) were treated syndromically according to the Ugandan Ministry of Health Clinical Guidelines for STI management. ${ }^{17}$ Participants treated for VDS and PID received $2 \mathrm{~g}$ of metronidazole in a single dose or $400 \mathrm{mg}$ of metronidazole twice daily for 14 days, respectively. ${ }^{17}$ In accordance with guidelines, women with asymptomatic laboratory-diagnosed BV were not treated. Women with laboratory-diagnosed asymptomatic STIs were treated. All participants with confirmed HIV infection were referred to an HIV care centre.

\section{Laboratory testing}

A vaginal swab was used to prepare a Gram-stained slide that was examined for vaginal yeast and for BV using Nugent score. ${ }^{18}$ A Nugent score of $0-3$ indicated normal microbiota, 46 indicated intermediate microbiota and 7-10 indicated BV. Another vaginal swab was inoculated in an InPouch culture for Trichomonas vaginalis and read daily for motile trichomonads for 5 days or until positive. A cervical swab was used to test for Neisseria gonorrhoeae and Chlamydia trachomatis using the Roche Amplicor C. trachomatis/N. gonorrhoeae PCR test. A single HIV Abbott Determine HIV-1/2 rapid test was performed onsite at the GHWP laboratory. Negative results were given to the participant immediately. Positive samples were sent to the MRC/UVRI serology laboratory in Entebbe for confirmation using Vironostika Uniform II (plus O) and Murex HIV EIA tests performed in parallel. Discordant or equivocal tests were retested by western blot to resolve the status. HIV-negative participants were routinely retested at subsequent visits. Syphilis serology was assessed using a quantitative Biotec rapid plasma reagin (RPR) test and the Treponema pallidum haemagglutination test (TPHA). Active syphilis was defined if both RPR and TPHA tests were positive, and an RPR titre of $\geq 1: 8$ was considered high-titre active syphilis. HSV-2 serology was performed using the HSV Type 2-IgG Kalon ELISA.

\section{Statistical methods}

Analyses were performed using Stata/SE, V.13.1 (StataCorp, College Station, Texas, USA). BV was considered as a binary outcome: samples with Nugent score of 0-6 were considered BV negative and samples with Nugent scores 7-10 were considered BV positive. We assessed trends in BV prevalence over the follow-up using logistic regression with random effects to account for within-woman correlation. ORs for trend $\left(\mathrm{OR}_{\text {trend }}\right)$ were obtained to estimate the change in $\mathrm{BV}$ prevalence from one 3-monthly follow-up visit to the next.

For the risk factor analysis, we examined factors associated with prevalent BV throughout the study period using a repeated-measures analysis (random-effects logistic regression). p-Values were obtained using likelihood ratio tests. Incident HIV and HSV-2 infections were defined as a positive test after a previously negative test.

A multivariate logistic regression model was constructed using a modified hierarchical framework ${ }^{19}$ based on the following levels: (1) socio-demographic, (2) sexual and behavioural factors and (3) biological factors. Level 1 factors associated with BV $(\mathrm{p}<0.20)$ in the unadjusted model were included in an adjusted regression model and retained as level 1 variables if they remained independently associated with BV $(\mathrm{p}<0.10)$. Behavioural variables associated with BV $(\mathrm{p}<0.20)$, plus the retained level 1 variables, were then included in the multivariate model and retained as level 2 variables if they remained independently associated with BV after adjustment for the covariates in the model $(p<0.10)$. Associations with level 3 factors were assessed in the same way.

We also examined the effects of treatment on subsequent BV separately for previously untreated cases and cases treated with metronidazole at the last visit. For this analysis, we adjusted for all variables retained in the framework described above.

Lastly, to investigate the effect of treatment on time to next BV episode, we used Cox regression analysis and restricted the data to participants who were diagnosed with BV at the enrolment visit. We compared participants who were untreated, treated with $2 \mathrm{~g}$ of metronidazole and treated with $400 \mathrm{mg}$ of metronidazole for 14 days. A multivariate Cox regression model adjusted for all variables retained in the framework described above, and any reported genital symptoms. A Kaplan-Meier curve was used to illustrate the time to next diagnosis by treatment.

\section{RESULTS}

\section{Characteristics of study population at enrolment}

Of the 1214 women screened, 1027 (85\%) were eligible, consented and enrolled in the cohort. The median age of the cohort was 26 years, and the majority $(89.3 \%)$ were under 35 years. Over $90 \%$ had some level of education, although few $(10.3 \%)$ had completed higher than primary level. The majority $(63.9 \%)$ were separated or divorced and most had children. At enrolment, 69\% of women reported five or more partners in the last month. Two-thirds of participants reported at least five occasions of transactional sex in the past month. Most women $(60 \%)$ reported consistent use of condoms with clients in the past month, but $5 \%$ reported never using them. At enrolment, $56 \%$ of participants were assessed as problem drinkers by the CAGE questionnaire.

Most women (94\%) reported vaginal cleansing in the past three months. Over half used water and soap to cleanse $(57 \%)$ and $40 \%$ reported cleansing more than three times a day. Over half $(56 \%)$ reported intravaginal insertion at least once in the past three months, mostly using herbs or other traditional substances but also aerated drinks (eg, Coca-Cola), gels and saliva. Genital symptoms were common at enrolment (68\%) and included dysuria (11\%), genital itching (36\%) or burning $(21 \%)$, dyspareunia (22\%), lower abdominal pain (30\%), abnormal discharge $(40 \%)$ or ulcers/blisters (12\%); 61\%, 23\% and 7\% were treated at enrolment for VDS, PID and GUD, respectively. Prevalence of N. gonorrhoeae infection was $13 \%$, C. trachomatis was $9 \%$ and T. vaginalis was $17 \%$. Seroprevalences of HSV-2 (80\%) and HIV (37\%) were high.

\section{BV prevalence over time and untreated BV}

Of the 1027 women enrolled in the study, 69\% were retained in follow-up at 24 months with a median of four visits per woman (range 1-7), amounting to a total of 5801 total visits. Of these, $5568(96 \%)$ had an available Nugent score result and were included in the analyses. The per-visit BV prevalence was $57 \%$, and $88 \%$ of the entire cohort had at least one positive BV result. Of the women who attended all seven clinical visits, more than half $(58 \%)$ of the participants had a positive BV result for at least four of the seven visits. Of the 3184 visits with 
Table 1 Prevalence trends in bacterial vaginosis (BV) diagnosis over seven visits among those with Nugent results at each visit in a cohort of 1027 women at high risk in Kampala, Uganda (2008-2011)

\begin{tabular}{|c|c|c|c|c|c|c|c|c|c|c|}
\hline & $\begin{array}{l}\text { Enrolment } \\
n=1027\end{array}$ & $\begin{array}{l}3 \text { months } \\
n=886\end{array}$ & $\begin{array}{l}6 \text { months } \\
n=792\end{array}$ & $\begin{array}{l}9 \text { months } \\
\mathrm{n}=777\end{array}$ & $\begin{array}{l}12 \text { months } \\
n=759\end{array}$ & $\begin{array}{l}18 \text { months } \\
n=743\end{array}$ & $\begin{array}{l}24 \text { months } \\
n=584\end{array}$ & $\mathrm{OR}_{\text {trend }}{ }^{*}$ & p Valuet & Trend \\
\hline Normal & $354(35 \%)$ & $330(37 \%)$ & $308(39 \%)$ & $298(36 \%)$ & $301(40 \%)$ & $262(35 \%)$ & $202(35 \%)$ & $1.00(0.97$ to 1.04$)$ & 0.87 & $\leftrightarrow$ \\
\hline Intermediate & $100(10 \%)$ & $73(8 \%)$ & $60(8 \%)$ & $49(6 \%)$ & $29(4 \%)$ & $27(4 \%)$ & $14(2 \%)$ & $0.79(0.74$ to 0.84$)$ & $<0.001$ & $\downarrow$ \\
\hline BV & $573(56 \%)$ & $483(55 \%)$ & $424(54 \%)$ & $450(58 \%)$ & $429(57 \%)$ & $454(61 \%)$ & $368(63 \%)$ & 1.07 (1.04 to 1.11$)$ & $<0.001$ & $\uparrow$ \\
\hline BV treated with metronidazole $\ddagger$ & $400(70 \%)$ & $270(56 \%)$ & $177(42 \%)$ & $138(31 \%)$ & $103(24 \%)$ & $41(9 \%)$ & $22(6 \%)$ & 0.78 (0.75 to 0.82$)$ & $<0.001$ & $\downarrow$ \\
\hline BV with any genital symptoms§ & $402(70 \%)$ & $309(64 \%)$ & $243(57 \%)$ & $244(54 \%)$ & $227(53 \%)$ & $259(48 \%)$ & $159(43 \%)$ & $0.48(0.45$ to 0.52$)$ & $<0.001$ & $\downarrow$ \\
\hline
\end{tabular}

${ }^{*} \mathrm{OR}$ for trend in BV prevalence from one 3-monthly follow-up visit to the next.

tLikelihood ratio (LR) test $p$ values were used to examine whether the $O R_{\text {trend }}$ were likely to be due to chance.

¥This is a subset of the BV cases; treatment includes any participants with the diagnosis of BV and who were treated with $2 \mathrm{~g}$ of metronidazole in a single dose or 400 mg of metronidazole twice daily for 14 days at that visit.

$\S$ This is a subset of the BV cases; 'any genital symptoms' included dysuria, genital itching or burning, dyspareunia, lower abdominal pain, abnormal discharge or ulcers/blisters. Genital itching or burning, dysuria and ulcers/blisters are not treated with metronidazole in the syndromic management algorithm.

BV diagnosis, 2033 (64\%) had no signs or symptoms corresponding to a diagnosis of VDS or PID documented, and therefore, remained untreated in line with current guidelines. However, of these untreated BV cases, about half (46\%) reported at least one genital symptom and were not strictly asymptomatic.

Prevalence of $\mathrm{BV}$ at enrolment was $56 \%$, and there was a small increase over time $\left(\mathrm{OR}_{\text {trend }}=1.10 ; 95 \% \mathrm{CI} 1.05\right.$ to 1.14 per 3-month period) (table 1). However, there was a decrease in prevalence of $\mathrm{BV}$ with any genital symptoms and treated $\mathrm{BV}$ over time $\left(\mathrm{OR}_{\text {trend }}=0.48 ; 95 \%\right.$ CI 0.45 to $0.52, \mathrm{OR}_{\text {trend }}=0.77$; $95 \%$ CI 0.74 to 0.82 , respectively). We carried out a sensitivity analysis by restricting the data to the 584 participant samples available at 24 months, but the prevalences and trends remained unchanged (see online supplementary table S1).

\section{Factors associated with prevalent BV}

Associations of BV with socio-demographic factors are shown in table 2. In adjusted analyses, risk of BV was higher for women who were younger (adjusted p-trend $=0.004$ ) and had lower levels of education (adjusted p-trend=0.01). BV was independently associated with behavioural factors including increasing number of lifetime partners (adjusted p-trend $<0.001$ ), any alcohol use in the past three months $(\mathrm{aOR}=1.30$; 95\% CI 1.09 to 1.56) and decreased reported use of condoms with paying clients in the past month (adjusted p-trend <0.001).

BV was independently associated with biological factors after adjusting for socio-demographic and behavioural factors. The strongest positive association was observed for high-titre syphilis $(\mathrm{aOR}=2.93 ; 95 \% \mathrm{CI} 1.62$ to 5.39$)$. BV was also independently associated with prevalent $\mathrm{HIV}(\mathrm{aOR}=1.94$; 95\% CI 1.54 to 2.44) and HSV-2 infections ( $\mathrm{aOR}=1.69 ; 95 \%$ CI 1.27 to 2.24$)$, low-titre syphilis $(\mathrm{aOR}=1.47 ; 95 \% \mathrm{CI} 1.04$ to 2.09$)$ and N. gonorrhoeae infection ( $\mathrm{aOR}=1.30 ; 95 \% \mathrm{CI} 1.00$ to 1.70$)$. In contrast, participants with vaginal yeast had a strongly reduced risk of $\mathrm{BV}(\mathrm{aOR}=0.45 ; 95 \% \mathrm{CI} 0.34$ to 0.59$)$. There was some evidence that pregnancy and hormonal contraception were associated with a reduced risk of BV, especially use of depot medroxyprogesterone acetate (DMPA) injections $(\mathrm{aOR}=0.66 ; 95 \% \mathrm{CI}$ 0.50 to 0.86 vs no contraception).

\section{Effect of BV treatment on subsequent BV}

There was a strong association between BV and having been diagnosed with BV at the previous 3-month visit, irrespective of whether the participant had received treatment (table 3).
Women who had received treatment for their BV at a previous 3-month visit were four times more likely to test positive for BV than those with no previous $\mathrm{BV}$ diagnosis $(\mathrm{aOR}=4.35 ; 95 \% \mathrm{CI}$ 3.34 to 5.66 ). Among 853 treated BV cases, $72 \%$ tested positive again within 3 months.

Among women diagnosed with $\mathrm{BV}$ at enrolment $(\mathrm{N}=527)$, there was no difference in time to subsequent BV diagnosis between no treatment versus treatment with $2 \mathrm{~g}$ of metronidazole in a single dose or $400 \mathrm{mg}$ of metronidazole twice daily for 14 days (aHR: 0.87 ; 95\% CI 0.70 to 1.07 and aHR: 1.02 ; $95 \%$ CI 0.75 to 1.39 , respectively). Kaplan-Meier survival curves for next BV diagnosis are shown in figure 1. Of the women who had a subsequent BV episode, the overall median time to diagnosis was 99 days (range 57-796 days).

\section{DISCUSSION}

Our study showed a high prevalence of BV in a population at high risk of HIV and STIs-at any one visit, over half the participants tested were BV positive. In line with current management guidelines, half of all BV cases were not treated; yet there was no difference in time to a subsequent BV diagnosis between treated and untreated women with BV even after controlling for any genital symptoms. Given the known association of BV with STI/HIV, the high prevalence of BV and poor effectiveness of current treatment strategies pose a major public health problem in this population.

High prevalences of BV among female sex workers have been reported elsewhere in sub-Saharan Africa: 70\% in South Africa and $40 \%$ in Kenya. ${ }^{20} 21$ The strong association between BV and prevalent bacterial and viral STIs is consistent with previous studies. ${ }^{1}{ }^{4-6}$ While our analysis could not ascertain the direction of causation, the literature reports mechanisms for a causal relationship between BV and STI acquisition. Vaginal acidity has been shown to inhibit acquisition of $N$. gonorrhoeae, C. trachomatis, HSV-2 and HIV. ${ }^{2-25}$ During episodes of BV, lactobacilli, lactic acid and vaginal acidity are diminished, potentially increasing susceptibility to these infections. BV also induces an innate immune response in which cytokines associated with HIV acquisition are upregulated. ${ }^{26}$ In the classic transmission dynamics model of STIs, BV influences the transmission probability by increasing susceptibility to STIs. Importantly, half the participants had BV for over half their study visits, suggesting that a large proportion of participants may have long periods with increased susceptibility to STIs including HIV infection. In addition, BV also increases 
Table 2 Factors associated with bacterial vaginosis (BV) at all visits in a repeated-measures analysis of 1027 women at high risk in Kampala, Uganda (2008-2011)

\begin{tabular}{|c|c|c|c|}
\hline & $\begin{array}{l}\text { Visits with BV diagnosed/ } \\
\text { number of visits (\%) }\end{array}$ & $\begin{array}{l}\text { Unadjusted } \\
\text { OR ( } 95 \% \mathrm{Cl})\end{array}$ & $\begin{array}{l}\text { Adjusted } \\
\text { OR }(95 \% \mathrm{Cl})\end{array}$ \\
\hline Total & $3180 / 5569(57.1 \%)$ & & \\
\hline \multicolumn{4}{|l|}{ Socio-demographic factors (level 1$)^{*}$} \\
\hline Age (years; $n=5569$ ) & & $\mathrm{p}_{\text {trend }}=0.008$ & $p_{\text {trend }}=0.004$ \\
\hline $14-24$ & $1249 / 2111(59.2 \%)$ & 1 & 1 \\
\hline $25-34$ & $1623 / 2836(57.3 \%)$ & 0.89 (0.70 to 1.13$)$ & $0.87(0.69$ to 1.11$)$ \\
\hline $35+$ & $309 / 622(49.7 \%)$ & 0.56 (0.38 to 0.82$)$ & $0.54(0.37$ to 0.79$)$ \\
\hline Highest education $(n=5569)$ & & $p_{\text {trend }}=0.03$ & $\mathrm{p}_{\text {trend }}=0.01$ \\
\hline Higher than primary level & $305 / 585(52.1 \%)$ & 1 & 1 \\
\hline Primary school completed & $1246 / 2223(56.1 \%)$ & 1.19 (0.80 to 1.75$)$ & $1.21(0.82$ to 1.80$)$ \\
\hline Primary school not completed & $1352 / 2321(58.3 \%)$ & 1.31 (0.89 to 1.94$)$ & $1.37(0.93$ to 2.03$)$ \\
\hline Never attended school & $278 / 440(63.2 \%)$ & 1.81 (1.06 to 3.10$)$ & 1.91 (1.12 to 3.26$)$ \\
\hline Regular partner $(n=5566) \dagger$ & & $p=0.29$ & $\mathrm{p}=0.32$ \\
\hline No & $702 / 1273(55.2 \%)$ & 1 & 1 \\
\hline Yes & $2478 / 4293(57.7 \%)$ & 1.10 (0.92 to 1.33$)$ & 1.09 (0.91 to 1.32$)$ \\
\hline Number of live births $(n=5224) \dagger$ & & $\mathrm{p}_{\text {trend }}=0.06$ & $p_{\text {trend }}=0.52$ \\
\hline None & $140 / 202(69.3 \%)$ & 1 & 1 \\
\hline $1-2$ & $1570 / 2736(57.4 \%)$ & $0.62(0.34$ to 1.16$)$ & $0.66(0.36$ to 1.24$)$ \\
\hline $3-4$ & 959/1715 (55.9\%) & $0.56(0.30$ to 1.06$)$ & $0.67(0.35$ to 1.28$)$ \\
\hline$\geq 5$ & $309 / 571(54.1 \%)$ & 0.49 (0.24 to 0.99$)$ & $0.63(0.30$ to 1.33$)$ \\
\hline \multicolumn{4}{|l|}{ Sexual and behavioural factors (level 2) $\ddagger$} \\
\hline Age of first sex (years; $n=5357$ ) $\dagger$ & & $p=0.15$ & $\mathrm{p}=0.76$ \\
\hline$\leq 14$ & $1128 / 1881(60.0 \%)$ & 1 & 1 \\
\hline $15-16$ & $1182 / 2067(57.2 \%)$ & $0.87(0.66$ to 1.13$)$ & $0.93(0.72$ to 1.22$)$ \\
\hline $17-18$ & $603 / 1140(52.9 \%)$ & 0.69 (0.50 to 0.94$)$ & $0.85(0.62$ to 1.18$)$ \\
\hline$\geq 19$ & $152 / 269(56.5 \%)$ & $0.87(0.51$ to 1.51$)$ & $1.04(0.60$ to 1.79$)$ \\
\hline Number of lifetime sexual partners $(n=5569)$ & & $\mathrm{p}_{\text {trend }}<0.001$ & $\mathrm{p}_{\text {trend }}<0.001$ \\
\hline$<20$ & $347 / 690(50.3 \%)$ & 1 & 1 \\
\hline $20-50$ & $428 / 841(50.9 \%)$ & 1.05 (0.69 to 1.61$)$ & $1.05(0.69$ to 1.60$)$ \\
\hline $50+$ & $184 / 327(56.3 \%)$ & 1.37 (0.79 to 2.39$)$ & $1.39(0.80$ to 2.54$)$ \\
\hline Can't remember & $2222 / 3711(59.9 \%)$ & 1.73 (1.22 to 2.44$)$ & $1.79(1.26$ to 2.37$)$ \\
\hline Involvement in sex work $(\mathrm{N}=5564) \dagger$ & & $p=0.14$ & $\mathrm{p}=0.47$ \\
\hline Only reports sex work for employment & $1040 / 1719(60.5 \%)$ & 1 & 1 \\
\hline Reports sex work and other employment & $1789 / 3183(56.2 \%)$ & $0.86(0.71$ to 1.05$)$ & $0.90(0.75$ to 1.09$)$ \\
\hline Reports no sex work & $348 / 662(56.2 \%)$ & 0.78 (0.60 to 1.02$)$ & $1.01(0.72$ to 1.43$)$ \\
\hline \multicolumn{2}{|c|}{ Number of paying sex partners in the past month $(\mathrm{N}=5569)$} & $\mathrm{p}=0.09$ & $\mathrm{p}=0.79$ \\
\hline $0-4$ & $1005 / 1869(53.8 \%)$ & 1 & 1 \\
\hline $5-49$ & $1648 / 2806(58.7 \%)$ & $1.30(1.01$ to 1.67$)$ & $1.09(0.83$ to 1.43$)$ \\
\hline $50+$ or can't remember & $528 / 894(59.1 \%)$ & $1.31(0.93$ to 1.84$)$ & $1.01(0.70$ to 1.46$)$ \\
\hline \multicolumn{2}{|c|}{ Use of condoms with paying partners in the last month $(\mathrm{N}=5562) \dagger$} & $p=0.002$ & $\mathrm{p}_{\text {trend }}<0.001$ \\
\hline Never & $221 / 350(63.1 \%)$ & 1 & 1 \\
\hline Sometimes & $259 / 404(64.1 \%)$ & 0.99 (0.68 to 1.43$)$ & 0.99 (0.68 to 1.44$)$ \\
\hline Most of the time & $764 / 1223(62.5 \%)$ & 0.90 (0.65 to 1.24$)$ & $0.86(0.63$ to 1.19$)$ \\
\hline Always & $1374 / 2511(54.7 \%)$ & 0.70 (0.51 to 0.94$)$ & $0.68(0.50$ to 0.92$)$ \\
\hline Not applicable§ & $560 / 1074(52.1 \%)$ & $0.65(0.48$ to 0.90$)$ & $0.68(0.49$ to 0.93$)$ \\
\hline \multicolumn{2}{|l|}{ Alcohol use in the last three months $(\mathrm{N}=5567) \dagger$} & $p=0.002$ & $p=0.004$ \\
\hline No & $882 / 1705(51.7 \%)$ & 1 & 1 \\
\hline Yes & $2298 / 3862(59.5 \%)$ & 1.33 (1.11 to 1.59$)$ & 1.30 (1.09 to 1.56$)$ \\
\hline \multicolumn{2}{|l|}{ Illicit drug use in the last three months $(\mathrm{N}=5569)$} & $\mathrm{p}=0.07$ & $\mathrm{p}=0.35$ \\
\hline No & $2406 / 4277(56.3 \%)$ & 1 & 1 \\
\hline Yes & $775 / 1292(60.0 \%)$ & $1.20(0.99$ to 1.45$)$ & $1.10(0.81$ to 1.33$)$ \\
\hline \multicolumn{2}{|c|}{ Intravaginal cleansing in the last three months $(\mathrm{N}=5558) \dagger$} & $\mathrm{p}=0.29$ & $\mathrm{p}=0.28$ \\
\hline No & $183 / 334(54.8 \%)$ & 1 & 1 \\
\hline Yes, with water only & $1312 / 2346(55.9 \%)$ & 0.96 (0.68 to 1.36$)$ & $0.92(0.65$ to 1.30$)$ \\
\hline Yes, with soap & $1679 / 2878(58.3 \%)$ & 1.09 (1.03 to 2.02$)$ & 1.05 (0.75 to 2.58$)$ \\
\hline \multicolumn{2}{|c|}{ High-frequency cleansing in the last three months $(\mathrm{N}=5217)+$, } & $\mathrm{p}=0.60$ & $\mathrm{p}=0.37$ \\
\hline No & $2096 / 3636(57.7 \%)$ & 1 & 1 \\
\hline Yes & $892 / 1581(56.4 \%)$ & $0.96(0.81$ to 1.13$)$ & $0.93(0.78$ to 1.10$)$ \\
\hline
\end{tabular}


Table 2 Continued

\begin{tabular}{|c|c|c|c|}
\hline & $\begin{array}{l}\text { Visits with BV diagnosed/ } \\
\text { number of visits (\%) }\end{array}$ & $\begin{array}{l}\text { Unadjusted } \\
\text { OR }(95 \% \mathrm{CI})\end{array}$ & $\begin{array}{l}\text { Adjusted } \\
\text { OR }(95 \% \mathrm{Cl})\end{array}$ \\
\hline \multicolumn{2}{|l|}{ Insertion of a substance in the last three months $(\mathrm{N}=5568) \mathrm{t}^{*}{ }^{* *}$} & $\mathrm{p}=0.11$ & $p=0.02$ \\
\hline No & $2129 / 3660(58.2 \%)$ & 1 & 1 \\
\hline Yes & $1052 / 1908(55.1 \%)$ & $0.88(0.75$ to 1.03$)$ & 0.82 (0.69 to 0.97$)$ \\
\hline \multicolumn{4}{|l|}{ Biological factors (level 3 ) $\dagger \dagger$} \\
\hline Hormonal factors (contraception/pregnancy; $\mathrm{N}=5368) \dagger$ & & $\mathrm{p}=0.01$ & $p=0.02$ \\
\hline No contraception & $1419 / 2338(60.7 \%)$ & 1 & 1 \\
\hline Oral contraceptive pill & $321 / 365(56.8 \%)$ & 0.83 (0.56 to 1.23$)$ & 0.81 (0.56 to 1.17$)$ \\
\hline Depot progesterone injection & 675/1309 (51.8\%) & $0.63(0.47$ to 0.85$)$ & 0.66 (0.50 to 0.86$)$ \\
\hline Other‡¥ & $557 / 955(58.3 \%)$ & 0.94 (0.68 to 1.30$)$ & 1.02 (0.75 to 1.38$)$ \\
\hline Pregnant & $209 / 401(52.1 \%)$ & 0.61 (0.39 to 0.95$)$ & $0.73(0.48$ to 1.10$)$ \\
\hline \multicolumn{2}{|l|}{ Vaginal yeast $(\mathrm{N}=5567) \dagger$} & $\mathrm{p}<0.001$ & $\mathrm{p}<0.001$ \\
\hline No & $3012 / 5158(58.4 \%)$ & 1 & 1 \\
\hline Yes & $168 / 409(41.1 \%)$ & 0.44 (0.34 to 0.58$)$ & $0.45(0.34$ to 0.59$)$ \\
\hline \multicolumn{2}{|l|}{ Trichomonas vaginalis $(\mathrm{N}=5565) \dagger$} & $p=0.003$ & $\mathrm{p}=0.05$ \\
\hline No & $2728 / 4924(55.4 \%)$ & 1 & 1 \\
\hline Yes & $450 / 641(70.2 \%)$ & 1.44 (1.14 to 1.84$)$ & 1.27 (1.00 to 1.70$)$ \\
\hline \multicolumn{2}{|l|}{ Neisseria gonorrhoeae $(\mathrm{N}=5502) \dagger$} & $p=0.001$ & $p=0.05$ \\
\hline No & $2799 / 5012(55.9 \%)$ & 1 & 1 \\
\hline Yes & $350 / 490(71.4 \%)$ & 1.54 (1.19 to 1.99$)$ & 1.30 (1.00 to 1.70$)$ \\
\hline \multicolumn{2}{|l|}{ Chlamydia trachomatis $(\mathrm{N}=5543) \dagger$} & $\mathrm{p}=0.66$ & $\mathrm{p}=0.86$ \\
\hline No & $3010 / 5283(57.0 \%)$ & 1 & 1 \\
\hline Yes & $160 / 260(61.5 \%)$ & 1.08 (0.77 to 1.52$)$ & 1.03 (0.73 to 1.46$)$ \\
\hline \multicolumn{2}{|l|}{ Syphilis $(N=5527) \dagger$} & $p<0.001$ & $\mathrm{p}=0.001$ \\
\hline Negative & 2404/4395 (54.7\%) & 1 & 1 \\
\hline Past syphilis $(\mathrm{TPHA}+/ \mathrm{rpr}-)$ & $332 / 540(61.5 \%)$ & 1.40 (1.00 to 1.97$)$ & $1.17(0.84$ to 1.63$)$ \\
\hline Positive:low titre $(\mathrm{TPHA}+/ \mathrm{rpr}<8)$ & $311 / 450(69.1 \%)$ & 2.02 (1.43 to 2.85$)$ & 1.47 (1.04 to 2.09$)$ \\
\hline Positive:high titre (TPHA+/rpr $\geq 8)$ & $111 / 142(78.2 \%)$ & $3.02(1.71$ to 5.34$)$ & 2.95 (1.62 to 5.39$)$ \\
\hline \multicolumn{2}{|l|}{ Current herpes simplex virus (HSV)- 2 status $(\mathrm{N}=5555) \dagger$} & $p<0.001$ & $p=0.001$ \\
\hline Negative & $410 / 923(44.4 \%)$ & 1 & 1 \\
\hline Prevalent HSV & 2743/4593 (59.7\%) & 2.23 (1.68 to 2.95$)$ & 1.69 (1.27 to 2.24$)$ \\
\hline Incident HSV§§ & 23/39 (59.0\%) & 2.41 (1.07 to 5.40$)$ & 2.07 (0.88 to 4.84$)$ \\
\hline \multicolumn{2}{|l|}{ Current HIV status $(\mathrm{N}=5372) \dagger$} & $p<0.001$ & $p<0.001$ \\
\hline Negative & $1704 / 3355(50.8 \%)$ & 1 & 1 \\
\hline Prevalent HIV & 1317/1986 (66.3\%) & 2.35 (1.89 to 2.95$)$ & 1.94 (1.54 to 2.44$)$ \\
\hline Incident HIV§§ & $23 / 31(74.2 \%)$ & 3.88 (1.44 to 10.46$)$ & 2.69 (0.98 to 7.37$)$ \\
\hline \multicolumn{4}{|c|}{ 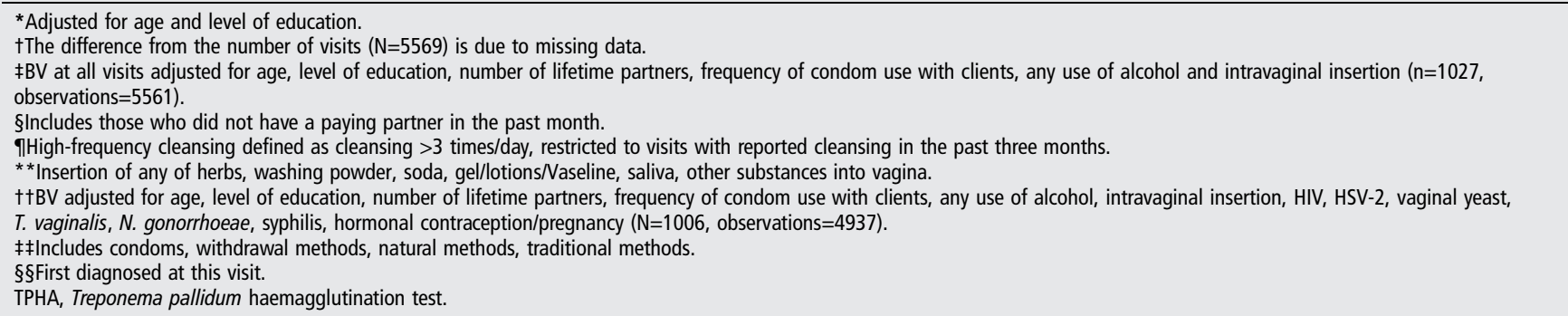 } \\
\hline
\end{tabular}

transmissibility of some viral STIs $;^{7}{ }^{8}$ therefore, women with multiple episodes of BV may have prolonged periods of increased infectiousness.

A 7-day metronidazole oral regimen of $500 \mathrm{mg}$ twice a day has been shown to provide an initial cure in $80-90 \%$ of BV cases (36); however, cure is seldom long term and recurrence is common. ${ }^{15}{ }^{14}$ In many resource-limited settings, women with symptomatic BV are managed according to national guidelines for the syndromic management of VDS and prescribed $2 \mathrm{~g}$ of metronidazole in a single dose. Previous research has shown that this is less efficacious than a 7 -day course, ${ }^{27}$ and that recurrence is more common than with longer regimens. ${ }^{28}$ Our study suggested a risk of a subsequent diagnosis following treatment of $>70 \%$. While some participants were treated with a 14 -day course of metronidazole as treatment for PID, the survival analysis showed no evidence of a difference in time to next BV diagnosis between no treatment, a single $2 \mathrm{~g}$ dose or 14-day course of metronidazole. For the latter treatment, nonadherence must be considered as a possible reason for persistent $\mathrm{BV}$, especially in populations with high alcohol use.

Interestingly, while there was an increase in overall BV prevalence over 24 months, there was a reduction in BV treated with metronidazole and a more modest reduction of BV with any symptoms. This apparent paradox may be better understood within an ecological model of vaginal microbiota in which antibiotic perturbation causes shifts in the microbiota. Indeed, 
Table 3 The association of bacterial vaginosis (BV) with treated or untreated BV at the visit 3 months prior at all visits in a repeated measures analysis of 1027 women at high risk in Kampala, Uganda (2008-2011)

\begin{tabular}{|c|c|c|c|}
\hline & $\begin{array}{l}\text { Number of BV cases } \\
\text { during follow-up } \\
\mathrm{n} / \mathrm{N}(\%)\end{array}$ & $\begin{array}{l}\text { Unadjusted } \\
\text { odds ratio }(95 \% \mathrm{Cl})\end{array}$ & $\begin{array}{l}\text { Adjusted } \\
\text { OR }(95 \% \mathrm{Cl})^{*}\end{array}$ \\
\hline Treatment for BV at visit 3 months prior $(N=3046) t$ & & $p<0.001$ & $\mathrm{p}<0.001$ \\
\hline No BV at previous visit & $331 / 1106(29.9 \%)$ & 1 & 1 \\
\hline Intermediate Nugent score at previous visit & $137 / 255(54.7 \%)$ & $2.72(2.02$ to 3.67$)$ & 2.42 (1.78 to 3.29$)$ \\
\hline Treated BV & $616 / 853(72.2 \%)$ & 5.19 (3.98 to 6.75$)$ & 4.35 (3.34 to 5.66$)$ \\
\hline Untreated BV & $611 / 832(73.4 \%)$ & 5.52 (4.23 to 7.21$)$ & 4.87 (3.74 to 6.34$)$ \\
\hline
\end{tabular}

different BV-associated bacterial species and their metabolites have been shown to be associated with different clinical criteria; ${ }^{29}$ for example, Atopobium vaginae is associated with vaginal discharge and high $\mathrm{pH}$, but not with an amine odour, while Prevotella bivia is associated with an amine odour and high $\mathrm{pH}$, but not vaginal discharge. Therefore, treatment may clear bacteria responsible for some types of symptoms, while other types may remain and overgrow, causing a modified clinical presentation or asymptomatic recurrent infection. More research is needed to understand the dynamics of the vaginal microbiota in this population in relation to treatment and recurrence.

Our study suggests that hormonal contraception may be protective against BV, and this has also been shown elsewhere. ${ }^{30}$ Therefore, the promotion of hormonal contraception may also be a potentially effective intervention to prevent $\mathrm{BV}$ in this population. Lactobacilli metabolise glycogen from oestrogenised epithelial cells; therefore, exogenous oestrogen in combined contraceptives is thought to promote Lactobacillus colonisation. In progesterone-only contraceptives, such as DMPA, it has been theorised that the reduction in menstruation is protective against BV. However, caution is needed in view of recent meta-analysis showing increased risk of HIV associated with DMPA. ${ }^{31}$

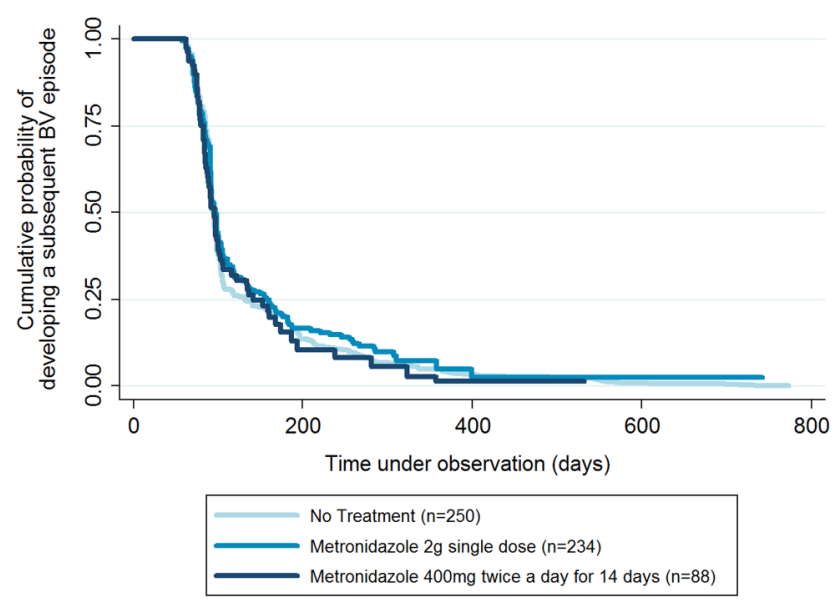

Figure 1 Kaplan-Meier survival curve demonstrating the time until subsequent diagnosis of bacterial vaginosis (BV) among 527 women diagnosed with BV at the enrolment visit in a cohort of 1027 women at high risk in Kampala, Uganda (2008-2011). This is over a 24-month period and stratified by treatment at the enrolment visit. The initial flat line reflects the intervals for scheduled clinic visits.
Strengths of our study included its longitudinal design and the high retention rate in a high-risk population, providing a rich data source to examine multiple correlates of BV over time, although some bias due to losses to follow-up cannot be excluded. There were some further limitations to our study. Shifts in vaginal microbiota can be rapid, causing short episodes of $\mathrm{BV}$ and fast response to treatment. ${ }^{32} \mathrm{BV}$ testing in this study was not designed to detect treatment success and was limited to 3 -month and 6-month intervals; however, the rates of repeat positive tests were similar to 3 -month recurrence rates observed in other treatment trials that included more intensive BV testing. ${ }^{14}$ Risk factors related to behaviours or infections of male partners were not measured in our study (eg, circumcision), and there may have been residual confounding if there were unmeasured or inaccurately measured risk behaviours.

In summary, for populations with high prevalence of BV and high HIV and STI incidence, more effective treatment strategies for BV are urgently needed. The development of innovative treatment strategies that effectively treat initial episodes of BV and prevent rapid recurrence should be a public health priority. Additionally, the potential role of hormonal contraceptives in the prevention of BV should be examined. Better treatments are required before carrying out trials to evaluate the impact of treatment of BV on the prevention of STIs, HIV or poor birth outcomes.

\section{Key messages}

- We found a very high prevalence $(56 \%)$ of bacterial vaginosis (BV) among women who are at high risk for HIV and sexually transmitted infections (STIS).

- Of the women who were treated for BV, $72 \%$ had a second episode by 3 months.

- In line with current management guidelines, half of all BV cases were not treated; yet there was no difference in time to a subsequent BV diagnosis between treated and untreated women with BV.

- This is the highest rate of recurrent diagnosis reported to date and highlights the need to focus efforts on improved treatment of BV for the prevention of STIS and HIV in populations of high risk.

Handling editor Jackie A Cassell

Acknowledgements The authors sincerely thank the study participants and the study team of the Good Health for Women Project in Kampala, the laboratory and 
data teams of the MRC/UVRI Unit in Entebbe and Women at Work International Uganda.

Contributors SCF and CL contributed equally. HG, RJH, JV, HAW, CL and SCF contributed to the conception and design of the work. JV, JB, YM, PH and SN contributed to the acquisition of the data for the work. SCF, CL and HAW performed the statistical analysis. CL and SCF drafted the manuscript. All authors contributed to revising it critically for important intellectual contact and approved of the final version.

Funding Financial support for this study was provided by the European and Developing Countries Clinical Trials Partnership (project code: CT_ct_05_32070_002) and from the UK Medical Research Council (MRC) and the Department for International Development (DFID) through a MRC/DFID concordat (Core Unit fund 88496) with HG and JV receiving salary support. Additionally, SCF (G1002369), HAW, RJH (G0700837) received salary support through MRC/DFID. The funders had no role in study design, data collection and analysis, decision to publish, or preparation of the manuscript.

Competing interests None declared.

Ethics approval Science and Ethics Committee of the Ugandan Virus Research Institute, the Ugandan National Committee for Science and Technology and the Ethics Committee of the London School of Hygiene and Tropical Medicine committee number 5198.

Provenance and peer review Not commissioned; externally peer reviewed.

Data sharing statement All authors have access to the original cohort data, database and study results. Further access to unpublished data is available upon request.

Open Access This is an Open Access article distributed in accordance with the terms of the Creative Commons Attribution (CC BY 4.0) license, which permits others to distribute, remix, adapt and build upon this work, for commercial use, provided the original work is properly cited. See: http://creativecommons.org/ licenses/by/4.0/

\section{REFERENCES}

1 Low N, Chersich MF, Schmidlin K, et al. Intravaginal practices, bacterial vaginosis, and HIV infection in women: individual participant data meta-analysis. PLOS Med 2011;8:e1000416.

2 Leitich $\mathrm{H}$, Bodneradler $\mathrm{B}$, Brunbauer $\mathrm{M}$, et al. Bacterial vaginosis as a risk factor for preterm delivery: a meta-analysis. Am J Obstet Gynecol 2003;189:139-47.

3 Hillier SL, Kiviat NB, Hawes SE, et al. Role of bacterial vaginosis-associated microorganisms in endometritis. Am J Obstet Gynecol 1996;175:435-41.

4 Cherpes TL, Meyn LA, Krohn MA, et al. Association between acquisition of herpes simplex virus type 2 in women and bacterial vaginosis. Clin Infect Dis 2003;37:319-25.

5 Wiesenfeld HC, Hillier SL, Krohn MA, et al. Bacterial vaginosis is a strong predictor of Neisseria gonorrhoeae and Chlamydia trachomatis infection. Clin Infect Dis 2003:36:663-8.

6 Balkus JE, Richardson BA, Rabe LK, et al. Bacterial vaginosis and the risk of trichomonas vaginalis acquisition among HIV-1-negative women. Sex Transm Dis 2014;41:123-8.

7 Cu-Uvin S, Hogan JW, Caliendo AM, et al. Association between bacterial vaginosis and expression of human immunodeficiency virus type 1 RNA in the female genital tract. Clin Infect Dis 2001;33:894-6.

8 Cherpes TL, Melan MA, Kant JA, et al. Genital tract shedding of herpes simplex virus type 2 in women: effects of hormonal contraception, bacterial vaginosis, and vaginal group B Streptococcus colonization. Clin Infect Dis 2005;40:1422-8.

9 Amsel R, Totten PA, Spiegel CA, et al. Nonspecific vaginitis. Diagnostic criteria and microbial and epidemiologic associations. Am J Med 1983;74:14-22. http://www. ncbi.nlm.nih.gov/pubmed/6600371 (accessed 22 Aug 2011).
10 Mlisana K, Naicker N, Werner L, et al. Symptomatic vaginal discharge is a poor predictor of sexually transmitted infections and genital tract inflammation in high-risk women in South Africa. J Infect Dis 2012;206:6-14.

11 Workowski KA, Berman S. Sexually transmitted diseases treatment guidelines, 2010 MMWR Recomm Rep 2010;59:1-110. http://www.ncbi.nlm.nih.gov/pubmed/ 21160459 (accessed 3 Jan 2014).

12 Sherrard J, Donders G, White D, et al. European (IUSTI/WHO) guideline on the management of vaginal discharge, 2011. Int J STD AIDS 2011;22:421-9.

13 World Health Organization. Guidelines for the management of sexually transmitted infections. Geneva: WHO, 2003.

14 Bradshaw CS, Morton AN, Hocking JS, et al. High recurrence rates of bacterial vaginosis over the course of 12 months after oral metronidazole therapy and factors associated with recurrence. J Infect Dis 2006;193:1478-86.

15 Myer L, Kuhn L, Denny L, et al. Recurrence of symptomatic bacterial vaginosis 12 months after oral metronidazole therapy in HIV-positive and -negative women. J Infect Dis 2006;194:1797-9.

16 Vandepitte J, Weiss HA, Bukenya J, et al. Alcohol use, mycoplasma genitalium, and other STIs associated With HIV incidence among women at high risk in Kampala, Uganda. J Acquir Immune Defic Syndr 2013;62:119-26.

17 Ministry of Health. Uganda clinical guidelines: National Guidelines on Management of Common Conditions. Kampala, Uganda, 2010.

18 Nugent RP, Krohn MA, Hillier SL, et al. Reliability of diagnosing bacterial vaginosis is improved by a standardized method of gram stain interpretation. J Clin Microbiol 1991;29:297-301. http://www.pubmedcentral.nih.gov/articlerender.fcgi? artid $=269757 \&$ tool $=$ pmcentrez\&rendertype $=$ abstract

19 Victora CG, Huttly SR, Fuchs SC, et al. The role of conceptual frameworks in epidemiological analysis: a hierarchical approach. Int J Epidemiol 1997;26:224-7.

20 Ramjee G, Karim SS, Sturm AW. Sexually transmitted infections among sex workers in KwaZulu-Natal, South Africa. Sex Transm Dis 1998;25:346-9. http://www.ncbi. nlm.nih.gov/pubmed/9713913 (accessed 8 Nov 2011).

21 Martin HL, Richardson BA, Nyange PM, et al. Vaginal lactobacilli, microbial flora, and risk of human immunodeficiency virus type 1 and sexually transmitted disease acquisition. J Infect Dis 1999;180:1863-8.

22 Graver MA, Wade JJ. The role of acidification in the inhibition of Neisseria gonorrhoeae by vaginal lactobacilli during anaerobic growth. Ann Clin Microbiol Antimicrob 2011;10:8.

23 Gong Z, Luna Y, Yu P, et al. Lactobacilli inactivate Chlamydia trachomatis through lactic acid but not H2O2. PLOS ONE 2014;9:e107758.

24 Conti C, Malacrino C, Mastromarino P. Inhibition of herpes simplex virus type 2 by vaginal lactobacilli. J Physiol Pharmacol 2009;60(Suppl 6):19-26.

25 Lai SK, Hida K, Shukair S, et al. Human immunodeficiency virus type 1 is trapped by acidic but not by neutralized human cervicovaginal mucus. J Virol 2009;83:11196-200.

26 Mitchell C, Marrazzo J. Bacterial Vaginosis and the Cervicovaginal Immune Response. Am J Reprod Immunol 2014;71:555-63.

27 Swedberg J, Steiner JF, Deiss F, et al. Comparison of single-dose vs one-week course of metronidazole for symptomatic bacterial vaginosis. JAMA 1985;254: 1046-9.http://www.ncbi.nlm.nih.gov/pubmed/3894707 (accessed 7 Mar 2014).

28 Koumans EH, Markowitz LE, Hogan V. Indications for therapy and treatment recommendations for bacterial vaginosis in nonpregnant and pregnant women: a synthesis of data. Clin Infect Dis 2002;35:S152-72.

29 Srinivasan S, Hoffman NG, Morgan MT, et al. Bacterial communities in women with bacterial vaginosis: high resolution phylogenetic analyses reveal relationships of microbiota to clinical criteria. PLOS ONE 2012;7:e37818.

30 Vodstrcil LA, Hocking JS, Law M, et al. Hormonal contraception is associated with a reduced risk of bacterial vaginosis: a systematic review and meta-analysis. PLOS ONE 2013;8:e73055.

31 Morrison CS, Chen PL, Kwok C, et al. Hormonal contraception and the risk of HIV acquisition: an individual participant data meta-analysis. PLOS Medicine 2015;21(1). doi:10.1371/journal.pmed.1001778.

32 Srinivasan S, Liu C, Mitchell CM, et al. Temporal variability of human vaginal bacteria and relationship with bacterial vaginosis. PLOS ONE 2010;5:e10197. 